\title{
Thrombomodulin as a New Marker of Lesion-Induced Astrogliosis: Involvement of Thrombin through the G-Protein-Coupled Protease- Activated Receptor-1
}

\author{
Armelle Pindon, ${ }^{1}$ Martin Berry, ${ }^{2}$ and Daniel Hantaï ${ }^{1}$ \\ 1/nstitut National de la Santé et de la Recherche Médicale Unité 523 (formerly 153), Institut de Myologie, Hôpital de la \\ Salpêtrière, F-75013 Paris, France, and 'Guy's, King's, and St. Thomas' School of Biomedical Sciences, Centre of \\ Neuroscience, Unit of Brain Damage and Repair, Guy's Campus, London SE1 1UL, United Kingdom
}

Because injury of the CNS causes an astrogliosis, characterized by cell swelling and proliferation, similar to the effects of the serine protease thrombin on astrocytes, we hypothesized that a high level of thrombin at the site of injury might initially induce an astrocyte reaction and later increase the expression of its specific inhibitor, thrombomodulin. Thrombomodulin could then stabilize the astroglial scar through its adhesive properties.

Here, we studied the in vivo injury response of astrocytes in the anterior medullary velum of adult rat by immunostaining and in situ hybridization of thrombomodulin. Thrombomodulin was poorly expressed on astrocytes in normal tissue, increased up to $2 \mathrm{~d}$ after injury, and was still highly expressed at $6 \mathrm{~d}$.

To check that thrombin had a direct effect on thrombomodulin expression by astrocytes, we used brain cortical astrocyte primary cultures treated with either thrombin or the agonist peptide thrombin receptor-activating peptide-6, known to activate directly the thrombin G-protein-coupled receptor (GPCR) protease-activated receptor-1 (PAR-1). Modification of thrombomodulin expression was studied by Western blotting and quantitative reverse transcription-PCR. There was a dosedependent increase in thrombomodulin after $48 \mathrm{hr}$ of treatment, with gene expression peaking at $24 \mathrm{hr}$ but falling to control levels by $48 \mathrm{hr}$.

Together, these results show the following: (1) injury increases astrocyte thrombomodulin expression; (2) thrombin might mediate thrombomodulin expression via the specific receptor PAR-1; and (3) serine proteases, their inhibitors, and the new family of GPCR, PARs, are active on astrogliosis.

Key words: astrocyte; glial scar; rat; serine protease; lesion; thrombomodulin
Astrocytes are implicated in several CNS processes throughout development and in aging. During adult life, astrocytes play a role in the homeostasis of brain extracellular ion balance achieved primarily through astrocytic potassium ionic buffering (Walz, 1989). Trauma and other pathological events in the CNS induce astrocytic scar reactions (Mathewson and Berry, 1985; Eng, 1988), characterized by hypertrophy, hyperplasia, and the accumulation of gliofilaments. Because we and others have shown previously that thrombin induced the same effects on cultured astrocytes (Beecher et al., 1994; Grabham and Cunningham, 1995; Pindon et al., 1998), we have studied the effects of this serine protease, generated in great amount at the site of a lesion, on astrocyte behavior in vivo.

Thrombin is a multifunctional serine protease, first described as cleaving fibrinogen into fibrin in the blood-clotting cascade (Stone and Le Bonniec, 1998). Thrombin has three specific G-protein-coupled receptors (GPCRs), protease-activated receptor-1, -3, and -4 (PAR-1, PAR-3, and PAR-4) (Vu et al., 1991; Ishihara et al., 1997; $\mathrm{Xu}$ et al., 1998) through which it activates a wide range of cells, including macrophages, bone cells,

\footnotetext{
Received Nov. 5, 1999; revised Jan. 3, 2000; accepted Jan. 14, 2000.

This work was supported by Institut National de la Santé et de la Recherche Médicale, the Association Française contre les Myopathies, and the French Institute on Spinal Cord Research.

Correspondence should be addressed to Dr. Armelle Pindon, Institut National de la Santé et de la Recherche Médicale Unité 523, Institut de Myologie, Groupe Hospitalier Pitié-Salpêtrière, 47, Boulevard de l'Hôpital, 75651 Paris Cedex 13, France. E-mail: inserm523@myologie.chups.jussieu.fr.

Copyright (C) 2000 Society for Neuroscience $0270-6474 / 00 / 202543-08 \$ 15.00 / 0$
}

and neurons (Gustafson and Lerner, 1983; Bar-Shavit et al., 1986; Gurwitz and Cunningham, 1988), inducing cell differentiation or growth, so that some authors view thrombin as a growth factor (Grand et al., 1996). What could be its influence on CNS lesions?

Thrombin is able to protect neurons and astrocytes from cell death (Vaughan et al., 1995; Donovan and Cunningham, 1998). Its action on astrocytes in vitro is concentration-dependent. In the nanomolar range, thrombin has a mitogenic effect (Perraud et al., 1987; Cavanaugh et al., 1990) and induces synthesis and release of NGF and endothelin (Ehrenreich et al., 1993; Neveu et al., 1993). In the picomolar range, thrombin induces morphological changes, reversing astrocyte stellation through the specific activation of PKC $\beta 1$ by PAR-1 (Pindon et al., 1998) but also through the activation of the small GTP-binding protein Rho (Suidan et al., 1997). Thus, because thrombin induces both astrocyte proliferation and shape changes similar to those characteristic of astrogliosis, it is possible that thrombin might be involved in the latter process.

Astrocyte and neuron behavior is governed by a delicate equilibrium between thrombin and its inhibitors. Until now, most of the studies on the thrombin inhibition in the CNS have been done on protease nexin 1 (PN1) (Monard, 1993). There is another thrombin inhibitor, thrombomodulin, which we have shown previously to be present and functionally active on primary astrocyte cultures (Pindon et al., 1997). Thrombomodulin is a transmembrane glycoprotein able to form a complex with the protease (Esmon, 1987). The lectin-like domain of thrombomodulin might 
involve the molecule in a new type of cell-cell adhesion (Imada et al., 1990).

We wanted to know whether thrombomodulin was involved in astrogliosis in vivo and whether thrombin was able to modulate its expression. We are the first to demonstrate that thrombomodulin is a new marker of astrogliosis in vivo after injury and that it upregulated in astrocyte primary cultures after thrombin administration.

\section{MATERIALS AND METHODS \\ Materials}

DMEM, fetal calf serum, and trypsin were from Life Technologies (Grand Island, NY). Human $\alpha$-thrombin was obtained from Enzyme Research Laboratories (Bloomington, IN), and thrombin receptoractivating peptide-6 (TRAP-6) (SFLLRN) was obtained from Bachem AG (Bubendorf, Switzerland). The anti-thrombomodulin 3E2 monoclonal antibody against human thrombomodulin was purchased from Serbio (Gennevilliers, France). The rat monoclonal and rabbit polyclonal antibodies against mouse thrombomodulin were a generous gift from Prof. Imada (Meiji Institute of Health Science, Odawara, Japan). The horseradish peroxidase-conjugated polyclonal antibodies against rabbit or rat immunoglobulin were from Dako (Glostrup, Denmark). The tetramethylrhodamine (TMR)-conjugated goat anti-rabbit IgG and fluorescein isothiocyanate (FITC)-conjugated goat anti-mouse IgG were from Jackson ImmunoResearch (West Grove, PA). The following items were supplied by Boehringer Mannheim (Mannheim, Germany): digoxigenin detection kit, sheep anti-digoxigenin-alkaline phosphatase Fab fragments, blocking reagent, digoxigenin in vitro transcription kit, EcoRI and HindIII enzymes, and proteinase $\mathrm{K}$. The sodium lauryl sarcosinate (Sarkosyl) was from Fluka Chemie AG (Buchs, Switzerland). The reverse transcription (RT)-PCR kit was purchased from Promega (Paris, France); Taq polymerase from Eurobio (Les Ulis, France); RT-PCR MIMIC construction kit from Clontech (Palo Alto, CA); and the enhanced chemiluminescence (ECL) kit from Amersham (Buckinghamshire, UK). The following were purchased from Sigma (St. Louis, MO): protease inhibitors (leupeptin, aprotinin, and pepstatin), nitro blue tetrazolium (NBT), and 5-bromo-4-chloro-3-indolyl phosphate (BCIP). All other chemicals were of reagent grade.

\section{Methods}

\section{Astrocyte cell culture}

All animal studies were approved by animal use procedures adopted by the Institut National de la Santé et de la Recherche Médicale. Neonatal (1- to 3-d-old) OF1 mice (IFFA CREDO, L'Arbresle, France) were anesthetized on ice and decapitated, and their brains were removed. After careful removal of the meninges, the cortex were passed through a $100 \mu \mathrm{m}$ mesh filter in DMEM containing 20\% fetal calf serum. The cells were seeded from a half cortex $/ 25 \mathrm{~cm}^{2}$ flask. Astrocytes were isolated from cortex following a protocol designed for newborn rats (McCarthy and Vellis, 1980), as modified previously for mice (Beecher et al., 1994). After $24 \mathrm{hr}$, the medium was removed, and cells were washed by pipetting PBS (in mM: $137 \mathrm{NaCl}, 2.7 \mathrm{KCl}, 6.7 \mathrm{Na}_{2} \mathrm{HPO}_{4}, 1.5 \mathrm{KH}_{2} \mathrm{PO}_{4}, 0.7 \mathrm{CaCl}_{2}$, and $0.5 \mathrm{MgCl}_{2}, \mathrm{pH} 7.4$ ) to remove loosely adherent cells, and, at day 3 , the medium was replaced by DMEM containing $10 \%$ fetal calf serum. When confluent, cells were washed twice with PBS and subsequently washed with $0.2 \mathrm{gm} / 1$ EDTA and $0.5 \mathrm{gm} / 1$ trypsin to remove oligodendrocytes. After trypsinization at $37^{\circ} \mathrm{C}$ for $5 \mathrm{~min}$, the cells were grown in DMEM containing $10 \%$ fetal calf serum. This culture contains $>90 \%$ astrocytes recognized by the presence of an astrocyte-specific protein, glial fibrillary acidic protein (GFAP).

\section{Cell treatment}

Cells were incubated in serum-free (thus thrombin-free) medium for at least $12 \mathrm{hr}$ before treatment. Cells were undergoing a single treatment with $2 \mathrm{nM} \alpha$-thrombin, TRAP-6 at different concentrations from $1.5 \mathrm{nM}$ to $150 \mu \mathrm{M}$, or, as a control, the vehicle (PBS), all at $37^{\circ} \mathrm{C}\left(5 \% \mathrm{CO}_{2}\right)$. Cells were left in the same medium and were collected 9, 24, 36, and 48 hr after treatment was initiated.

\section{Anterior medullary velum lesion}

Lesions were placed in the anterior medullary velum (AMV) (Berry et al., 1995) of Avertin-anesthetized, adult Wistar rats using a retractable,
A intact AMV

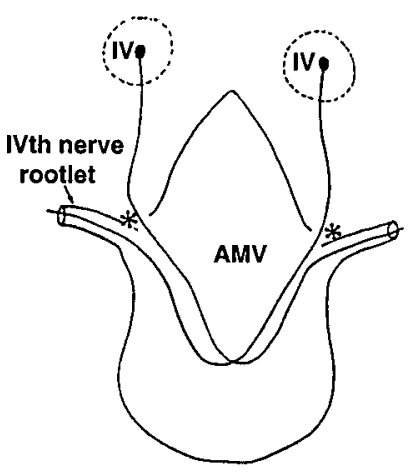

B transected AMV

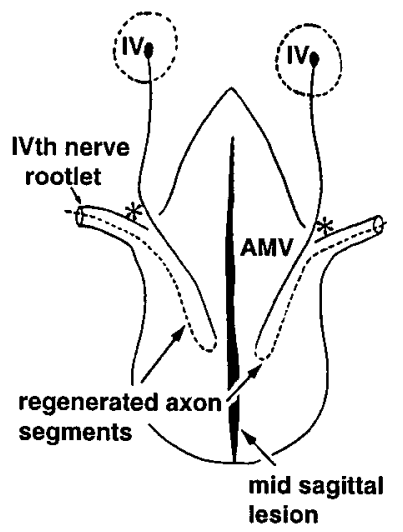

Figure 1. Schematic representation of whole mounts of rat AMV. $A$, Intact; $B$, transected by a midsagittal penetrant lesion. In the intact specimen, trochlear fibers from the ipsilateral IVth nucleus $(I V)$ in the midbrain invade the AMV at the entry point $(*)$; the majority decussate and exit in the contralateral IVth nerve rootlet $(A)$. Midsagittal transection of the crossing axons precipitates degeneration of all severed distal segments coursing contralaterally from the midline into each rootlet $(B)$. From the severed proximal stumps of IVth nerve fibers, regenerating sprouts grow into the ipsilateral halves of each velum, specifically directed into each ipsilateral IVth nerve rootlet, represented as dashed lines. Modified from Berry et al. (1998).

curved needle, guarded by a trochar, devised specifically for this purpose. With the needle withdrawn into the trochar, the instrument was introduced through the posterior atlanto-occipital membrane into the IVth ventricle until the tip of the instrument lay in the most rostral portion of the ventricle. Protrusion of the enclosed needle, at this point, brought its superiorly curving tip into contact with the AMV in the ventricular roof. Withdrawal of the instrument, with the needle protruded, thus produced a midsagittal lesion of the AMV, sometimes accompanied by a corresponding lesion of the overlying cerebellar vermis. Groups of five lesioned animals, of either sex, were killed $9 \mathrm{hr}$ postlesioning (hpl) and 1, 2 , and $6 \mathrm{~d}$ postlesioning (dpl). Animals were perfused with $4 \%$ paraformaldehyde (PAF) in PBS. The entire AMV, with trochlear nerves attached, was then dissected free from the inferior colliculi and rostroinferior surface of the cerebellum (Fig. 1) and transferred to distilled water.

\section{Immunohistochemistry on $A M V$}

Free-floating AMV were fixed again in 4\% PAF for 15 min, washed with PBS, permeabilized with $0.1 \%$ Triton X-100 overnight, and then washed twice in PBS. Saturation was performed for $2 \mathrm{hr}$ in PBS containing $0.1 \%$ BSA (PBS-BSA) and $1 \%$ normal goat serum at $4^{\circ} \mathrm{C}$. Double-staining was performed by incubating monoclonal 3E2 anti-thrombomodulin and polyclonal anti-GFAP antibodies with a dilution of 1:100 in PBS-BSA, overnight at $4^{\circ} \mathrm{C}$. AMV were washed twice for $5 \mathrm{~min}$ and once for $10 \mathrm{~min}$ in PBS and then incubated for $1 \mathrm{hr}$ at $4^{\circ} \mathrm{C}$ with secondary antibodies, TMR-conjugated goat anti-rabbit IgG, and FITC-conjugated goat antimouse IgG diluted in PBS-BSA at 1:250 and 1:200, respectively. AMV were washed twice for $5 \mathrm{~min}$ and once for $10 \mathrm{~min}$ in PBS, then fixated in $4 \%$ PAF for 10 min before mounting and viewing with a Zeiss (Oberkochen, Germany) Axiophot fluorescence microscope or a Leica (Nussloch, Germany) TCS 4D confocal microscope.

\section{Synthesis of digoxigenin-labeled riboprobes}

Sense and antisense riboprobes were synthesized. Five micrograms of plasmid containing the thrombomodulin cDNA fragment of $418 \mathrm{bp}$ (described by Pindon et al., 1997) were opened by incubating either EcoRI or HindIII for $1 \mathrm{hr}$ at $37^{\circ} \mathrm{C}$, precipitated in $0.15 \mathrm{M}$ sodium acetate, $\mathrm{pH} \mathrm{5}$, and $50 \%$ of phenol-chloroform, and centrifuged for $5 \mathrm{~min}$ at $12,000 \times g$. The pellet was washed with $70 \%$ ethanol and resuspended in $4 \mu \mathrm{l}$ of $\mathrm{H}_{2} \mathrm{O}$. Riboprobes were synthesized with $1 \mu \mathrm{l}$ of this suspension using an in vitro transcription SP6/T7 digoxigenin labeling kit. The reaction was performed with $\mathrm{T} 3$ polymerase for the sense probe and $\mathrm{T} 7$ polymerase for the antisense probe, using the digoxigenin-UTP nucleo- 
tides mix, in the presence of RNase, for $2 \mathrm{hr}$ at $37^{\circ} \mathrm{C}$ and then for $10 \mathrm{~min}$ with $2 \mu \mathrm{l}$ of DNase. RNA were precipitated by incubating overnight at $-20^{\circ} \mathrm{C}$ in the presence of $100 \mu \mathrm{l}$ of TE buffer $(10 \mathrm{~mm}$ Tris- $\mathrm{HCl}$ and 0.1 mм EDTA, pH 7.5).

\section{In situ hybridization}

Free-floating AMV were washed twice for $5 \mathrm{~min}$ in PBS- $0.1 \%$ Tween 20 (PBST), dipped successively in 50\% methanol-PBST and $75 \%$ methanol-PBST for $2 \mathrm{~min}$, quickly dipped in 50\% methanol-PBST and 25\% methanol-PBST, and given two 5 min washes in PBST. AMV were treated with $10 \mu \mathrm{g} / \mathrm{ml}$ proteinase $\mathrm{K}$ for $10 \mathrm{~min}$, fixed with 4\% PAF in PBS containing $4 \mu \mathrm{l} / \mathrm{ml} 25 \%$ glutaraldehyde for $15 \mathrm{~min}$, washed once with PBST for $5 \mathrm{~min}$, and put in a solution of 50\% PBST and 50\% hybridization $\mathrm{mix}(50 \%$ formamide, $1.3 \times \mathrm{SSC}, 5 \mathrm{~mm}$ EDTA, $100 \mu \mathrm{g} / \mathrm{ml}$ heparin, $50 \mu \mathrm{g} / \mathrm{ml}$ yeast RNA, $0.2 \%$ Tween 20 , and $0.5 \%$ CHAPS). After washing three times for $5 \mathrm{~min}$ with hybridization mix. AMV were incubated overnight at $65^{\circ} \mathrm{C}$ in the mix containing the probe at a concentration of $10 \mu \mathrm{l} / \mathrm{ml}$, washed twice for $30 \mathrm{~min}$ in hybridization mix at $65^{\circ} \mathrm{C}$ and then for $20 \mathrm{~min}$ at $65^{\circ} \mathrm{C}$ in $50 \%$ hybridization mix-50\% MABT solution (100 mm maleic acid, $1150 \mathrm{~mm} \mathrm{NaCl}$, and $0.1 \%$ Tween $20, \mathrm{pH}$ 7.5), rinsed three times in MABT at room temperature, and finally incubated for $30 \mathrm{~min}$ with $300 \mathrm{ml}$ of MABT, $100 \mathrm{ml}$ of blocking reagent (from the kit), and $100 \mathrm{ml}$ of normal goat serum. The immunodetection of the probe was performed overnight at $4^{\circ} \mathrm{C}$ in the same solution as above containing the antibody anti-digoxigenin-alkaline phosphatase at 1:2000. AMV were given three $5 \mathrm{~min}$ and three $1 \mathrm{hr}$ washes with MABT, incubated twice for $10 \mathrm{~min}$ in the NTMT solution $(0.1 \mathrm{M} \mathrm{NaCl}, 0.1 \mathrm{M}$ Tris-HCl, $\mathrm{pH}$ 9.5, $0.05 \mathrm{M} \mathrm{MgCl}_{2}$, and $1 \%$ Tween 20), and incubated at room temperature in the dark in NTMT containing $4.5 \mu \mathrm{l} / \mathrm{ml} \mathrm{NBT}$ and $3.5 \mu \mathrm{l} / \mathrm{ml}$ BCIP (X-phosphate). The reaction was stopped by washing with PBST. AMV were then processed as whole mounts as above for microscopy.

\section{Cell fractionation}

Cells were washed twice with PBS, placed into ice-cold $0.02 \mathrm{M}$ Tris-HCl buffer, $\mathrm{pH} 7.5$, containing a cocktail of protease inhibitors $(0.5 \mu \mathrm{g} / \mathrm{ml}$ leupeptin, $1.25 \mu \mathrm{g} / \mathrm{ml}$ aprotinin, and $0.5 \mu \mathrm{g} / \mathrm{ml}$ pepstatin), disrupted with a glass homogenizer at $4^{\circ} \mathrm{C}$, and ultracentrifuged at $105,000 \times g$ for 30 min at $4^{\circ} \mathrm{C}$ in an ultracentrifuge (Beckman, Palo Alto, CA). The supernatant consisted of the cytosolic fraction. The pellet was resuspended in ice-cold $0.01 \mathrm{~m}$ Tris-HCl, pH 6.8, containing $1 \%$ Triton X-100, for $20 \mathrm{~min}$ at $4^{\circ} \mathrm{C}$, and again centrifuged at $105,000 \times g$ for $30 \mathrm{~min}$. The supernatant of this final centrifugation consisted of the solubilized membrane protein fraction.

\section{Western immunoblotting}

After cell fractionation, membrane fraction protein extracts $(10 \mu \mathrm{g} /$ well $)$ were resolved on $10 \%$ SDS-PAGE (Laemmli, 1970) and subsequently transferred to a nitrocellulose membrane (Towbin et al., 1979) in $0.025 \mathrm{M}$ Tris, $0.192 \mathrm{M}$ glycine, and $10 \%$ isopropanol, $\mathrm{pH} 8.3$, buffer. Membranes were incubated for $2 \mathrm{hr}$ at $25^{\circ} \mathrm{C}$ with PBS containing $10 \%$ instant nonfat dry milk. They were subsequently incubated overnight in PBS containing $5 \%$ instant nonfat dry milk, along with either a polyclonal or monoclonal antibody against mouse thrombomodulin, washed once for $5 \mathrm{~min}$ and three times for $15 \mathrm{~min}$ in PBS- $0.05 \%$ Tween 20 . They were then incubated for $1 \mathrm{hr}$ at room temperature with either a peroxidaseconjugated polyclonal goat anti-rabbit $\operatorname{IgG}$ antibody or a mouse $\operatorname{IgG}$ antibody and washed again as above. Finally, immunoreactive bands were revealed using ECL reagents (Amersham) and visualized on Kodak (Eastman Kodak, Rochester, NY) X-OMAT AR film. Western blots were quantified using the MCID-M4 software (Imaging Research Inc., St Catharines, Ontario, Canada).

\section{RNA extraction}

Total RNA was prepared according to Chomczynski and Sacchi (1987). Cells were washed with PBS at $4^{\circ} \mathrm{C}$ and lysed in $4 \mathrm{~m}$ guanidium thiocyanate, $25 \mathrm{~mm}$ sodium citrate, $\mathrm{pH} 7.5,0.5 \%$ Sarkosyl, and $0.1 \mathrm{M} \beta-2$ mercaptoethanol. The total amount of RNA was determined by measuring its absorbance at $260 \mathrm{~nm}$ in a Beckman DU-70 spectrophotometer.

\section{Competitive RT-PCR mimic}

This method uses a PCR mimic DNA that contains complementary sequences of primers identical to the sequences found on the thrombomodulin cDNA used in conventional thrombomodulin PCR. Known amounts of mimic DNA were mixed with the thrombomodulin cDNA and competed together for the PCR. When the intensity of PCR products were equal for mimic DNA and thrombomodulin cDNA, we estimated that titers of both were equal.

PCR mimic construction. Construction of the PCR mimic was performed using the RT-PCR MIMIC kit from Clontech. A primary PCR amplification of $2 \mathrm{ng}$ of a $554 \mathrm{bp}$ neutral DNA fragment (BamHI/EcoRI of v-erbB) was performed using the PCR kit from Promega. The composite primers were $5^{\prime}$ TGGTGTGGTCAATGTCCGCAAGTGAAAT CTCCTCCG 3' and 5' AGTGTCGGTGGTAAGATTGAGTCCATGG GGAGCTTT 3'. The PCR was performed in a total volume of $50 \mathrm{ml}$ with $1.5 \mathrm{mM} \mathrm{MgCl}_{2}, 2.5 \mathrm{U} \mathrm{Taq}$ polymerase, and $0.4 \mu \mathrm{M}$ composite primers. The reaction cycles were 1 cycle at $95^{\circ} \mathrm{C}$ for $5 \mathrm{~min}$ and 30 cycles of three segments: $45 \mathrm{sec}$ at $94^{\circ} \mathrm{C}, 45 \mathrm{sec}$ at $50^{\circ} \mathrm{C}$, and $90 \mathrm{sec}$ at $72^{\circ} \mathrm{C}$. The PCR product was diluted at 1:100 and ran for a second PCR amplification using $1 \mathrm{mM} \mathrm{MgCl}_{2}, 2.5 \mathrm{U} \mathrm{Taq}$ polymerase, and $0.4 \mu \mathrm{M}$ primers as described by Pindon et al. (1997).

PCR mimic purification and estimation. PCR products were loaded on chroma spin TE- 100 columns and then centrifuged at $700 \times g$ for $5 \mathrm{~min}$. The product and different concentrations of fX174 DNA were resolved on a $1 \%$ agarose gel electrophoresis. Comparison of band intensities gave the mimic concentration in nanograms per milliliter. We calculated the mimic DNA concentration in attomoles per milliliter because the molecular weight of the mimic was $604 \times 600=398,640 \mathrm{gm} / \mathrm{mol}$. We diluted the mimic DNA to $100 \mathrm{amol} / \mathrm{ml}$ in TE buffer.

Preliminary competitive PCR amplification. Thrombomodulin cDNA was obtained by performing retrotranscription with $3 \mu \mathrm{g}$ of astrocyte total RNA using the Promega kit; RNA was heated for 3 min at $65^{\circ} \mathrm{C}$, added to the reaction medium from the Promega kit, and incubated for $40 \mathrm{~min}$ at $42^{\circ} \mathrm{C}$. Serial dilution of mimic DNA was performed in TE buffer to obtain nine concentrations from $100 \mathrm{amol} / \mathrm{ml}$ to $10^{-6} \mathrm{amol} / \mathrm{ml}$. Competitive PCR were run in 96-well plates with serial dilutions of PCR mimic competing with a constant amount of thrombomodulin cDNA. PCR were performed with $2 \mu \mathrm{l}$ of a mimic DNA concentration, $2 \mu \mathrm{l}$ of the retrotranscription product, and $46 \mu \mathrm{l}$ of PCR reaction buffer $(1 \mathrm{~mm}$ $\mathrm{MgCl}_{2}, 2.5 \mathrm{U} \mathrm{Taq}$ polymerase, and $0.4 \mu \mathrm{M}$ of thrombomodulin primers). PCR was run as described by Pindon et al. (1997). PCR products were resolved on a $1 \%$ agarose gel, size markers used were Boehringer markers IV, mimic DNA is $604 \mathrm{bp}$, and thrombomodulin cDNA fragment is $418 \mathrm{bp}$. Comparison of the intensity of the two bands, mimic DNA and thrombomodulin cDNA, in each independent well gave an estimation of the cDNA amount and determined the dilution range to be used in the fine-tuned competitive PCR amplification.

Fine-tuned competitive PCR amplification. A twofold dilution series was made with mimic DNA (i.e., from $10^{-2}$ to $0.31210^{-3} \mathrm{amol}$ ), and PCR was run in 96-well plates with $2 \mu \mathrm{l}$ of a mimic DNA, $2 \mu \mathrm{l}$ of the astrocyte total RNA retrotranscription product, and $46 \mu \mathrm{l}$ of PCR reaction buffer, as described above. PCR products were resolved on a $1 \%$ agarose gel, and the amount of thrombomodulin fragment cDNA was determined by comparing the intensity of the two bands in each independent PCR. The concentration of cDNA was equal to the one of mimic DNA when the two bands had the same intensity.

\section{RESULTS}

\section{Thrombomodulin expression in the lesioned AMV}

\section{Protein expression: immunohistochemistry}

The protein expression of thrombomodulin was studied by immunohistochemistry on permeabilized AMV at different times after lesion: 0 and $9 \mathrm{hpl}$ and 1, 2, and $6 \mathrm{dpl}$. To visualize astrocytes and thrombomodulin, double-staining was performed. Cells were labeled with anti-GFAP antibody specific for astrocytes and a marker of astrogliosis (Bignami et al., 1972) and anti-human thrombomodulin monoclonal antibody. Immunohistochemistry was visualized in the $\mathrm{z}$ plan of the tissue that contained astrocytes using a confocal microscope.

Immediately after lesion, thrombomodulin was weakly expressed in the AMV up to $9 \mathrm{hpl}$ but increased after $1 \mathrm{dpl}$ (Fig. $2 A, D, G)$. Thrombomodulin protein expression was maximal at 2 dpl but decreased at $6 \mathrm{dpl}$ (Fig. $2 J, M)$. However, thrombomodulin expression was more intense at $6 \mathrm{dpl}$ than in controls. GFAP was present at all times after lesion, compatible with the astro- 

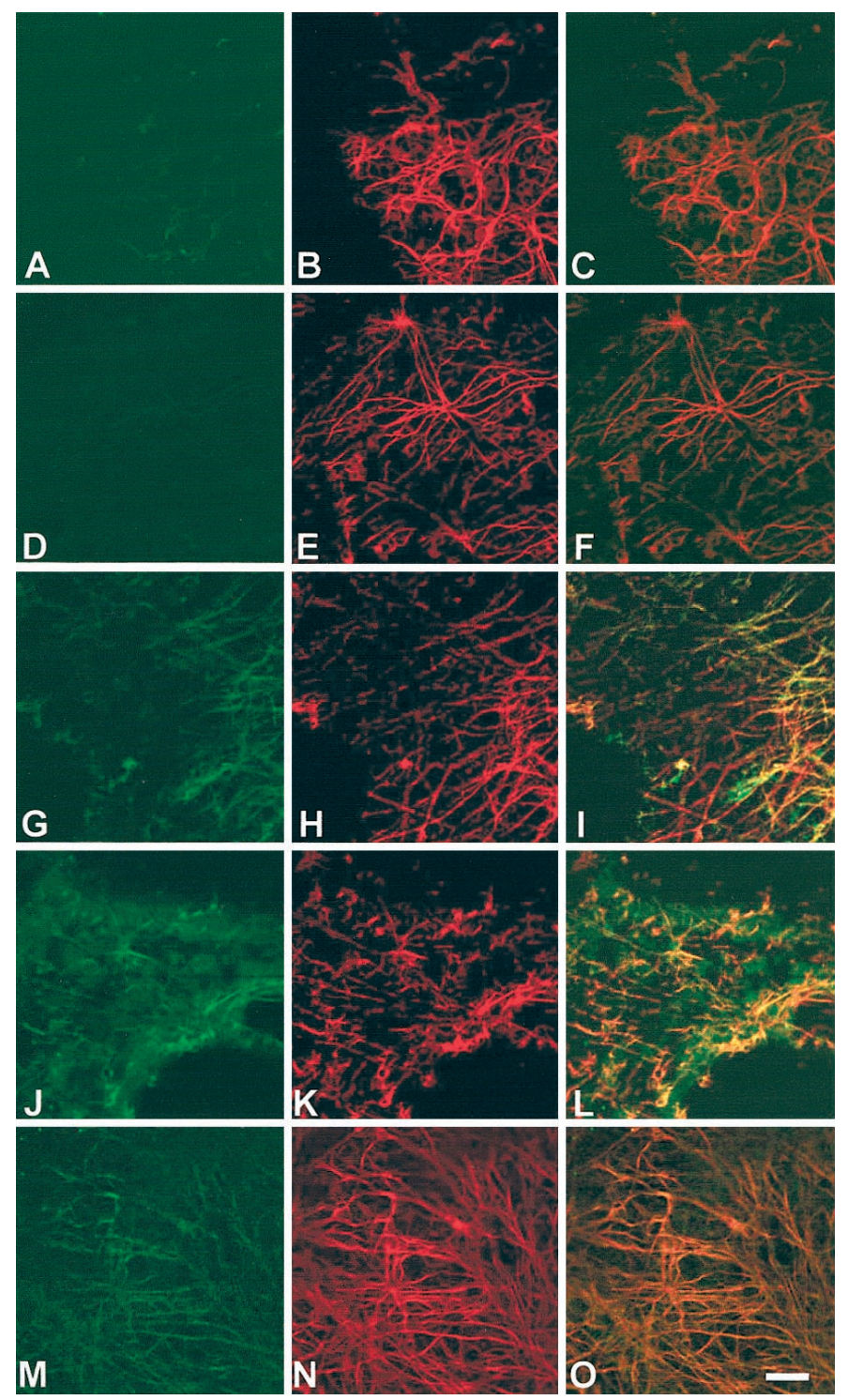

Figure 2. Thrombomodulin protein increases on astrocytes after lesion of the AMV. Double-immunolabeling by thrombomodulin (left) and GFAP (middle) of astrocytes of whole mounts of AMV at different times after lesioning as observed by confocal microscopy. Times after lesion are as follows: $0 \mathrm{hpl}(A-C) ; 9 \mathrm{hpl}(D-F) ; 1 \mathrm{dpl}(G-I) ; 2 \mathrm{dpl}(J-L)$; and $6 \mathrm{dpl}$ $(M-O)$. Immunohistochemistry was performed with monoclonal 3E2 anti-thrombomodulin and polyclonal anti-GFAP antibodies, which were revealed by fluorescein isothiocyanate-conjugated (green) and tetramethylrhodamine-conjugated (red) secondary antibodies, respectively. Colocalization of thrombomodulin and GFAP on astrocytes is shown by yellow (right), maximal at $2 \mathrm{dpl}$. Pictures represent a representative sample of five experiments. Scale bar, $50 \mu \mathrm{m}$.

gliosis (Fig. 2B, E, $H, K$ ). Thrombomodulin and GFAP were colocalized (Fig. 2I,L,O), showing that thrombomodulin coated reactive astrocytes after lesioning.

\section{mRNA expression: in situ hybridization}

Thrombomodulin mRNA was revealed by in situ hybridization with a riboprobe in which uracil bases were coupled with digoxigenin. Phosphatase alkaline-coupled antibodies against digoxigenin were used and revealed by precipitation of diformazan.

Thrombomodulin mRNA was not detected in AMV at $0 \mathrm{hpl}$ (Fig. $3 A$ ) but first appeared at $9 \mathrm{hpl}$, and the level of expression increased to become maximal by $1-2 \mathrm{dpl}$ (Fig. $3 B-D$ ). At $2 \mathrm{dpl}$, the expression of thrombomodulin mRNA was localized within a limited area around the site of the lesion delineating a clear boundary outside of which no staining was detected (Fig. 3F). Thrombomodulin mRNA was still expressed around the lesion at $6 \mathrm{dpl}$ but with a weaker intensity (Fig. $3 E$ ). Controls, performed with sense probe, did not show any specific staining in the AMV. The staining seen on the border of the tissue (Fig. $3 A-E$ ) is a nonspecific edge effect also observed in negative control sense riboprobe.

To show that thrombomodulin mRNA expression was localized on astrocytes, we performed immunohistochemistry revealing GFAP on AMV already processed for thrombomodulin mRNA in situ hybridization. We visualized the staining with confocal microscopy to be in the precise $\mathrm{z}$ plan of the astrocytes. Because of technical limitation of confocal microscopy, it is not possible to visualize the diformazan precipitate under visible light. Nevertheless, it was possible to see the mRNA in an indirect way; the presence of the diformazan precipitate quenches the fluorescent immunostaining and shows instead a negative dark surface. The GFAP immunohistochemistry performed alone on AMV shows staining of astrocyte cell bodies (Fig. 4A). However, when performed after in situ hybridization, only astrocyte processes were stained, whereas astrocyte cell bodies were dark (Fig. 4B). We concluded that thrombomodulin mRNA was colocalized within astrocytes.

\section{Thrombomodulin expression was modulated by thrombin treatment}

Thrombomodulin protein expression after thrombin treatment

Astrocyte primary cultures were grown in serum-free conditions for at least $12 \mathrm{hr}$ and treated with a single dose of $\alpha$-thrombin at $2 \mathrm{~nm}$. Cells were harvested 9, 24, 36, and $48 \mathrm{hr}$ after the treatment. The membrane fraction was resolved by Western blot analysis. We have shown previously that mouse thrombomodulin is present in astrocytes (Pindon et al., 1997) and appears in Western blots with a molecular mass of 70 and $140 \mathrm{kDa}$ as described previously (Imada et al., 1987). Because this was the expected molecular mass of thrombomodulin, we focused the quantification on the $70 \mathrm{kDa}$ band. We show here that, $9 \mathrm{hr}$ after thrombin treatment, thrombomodulin localized in the membrane fraction disappeared (Fig. 5A). The protein appeared $24 \mathrm{hr}$ after treatment, at the same level of expression as in controls (Fig. $5 \mathrm{~A}, \mathrm{C}$ ). Then, thrombomodulin levels increased and more than doubled $48 \mathrm{hr}$ after thrombin treatment (Fig. $5 A, C$ ). No significant modification of thrombomodulin levels were observed (Fig. $5 B$ ) after repeating the above experiments with $2 \mathrm{nM} \alpha$-thrombin previously incubated for $5 \mathrm{~min}$ at $37^{\circ} \mathrm{C}$ with $10 \mathrm{U} / \mathrm{ml}$ hirudin, a thrombin inhibitor.

\section{Protein expression after PAR-1-specific activation}

To determine whether a thrombomodulin increase induced by thrombin was dependent on PAR-1 activation, we performed a dose-response curve with TRAP-6, a specific activator of PAR-1 (Fig. 6). Astrocytes were incubated for $48 \mathrm{hr}$ because thrombomodulin expression was found to be doubled at this time (see above). We found that the thrombomodulin $70 \mathrm{kDa}$ band, which is the predicted molecular mass of the protein, was upregulated by PAR-1 activation. The effect of PAR-1 activation on thrombomodulin levels started from $1.5 \mu \mathrm{M}$ TRAP-6. 

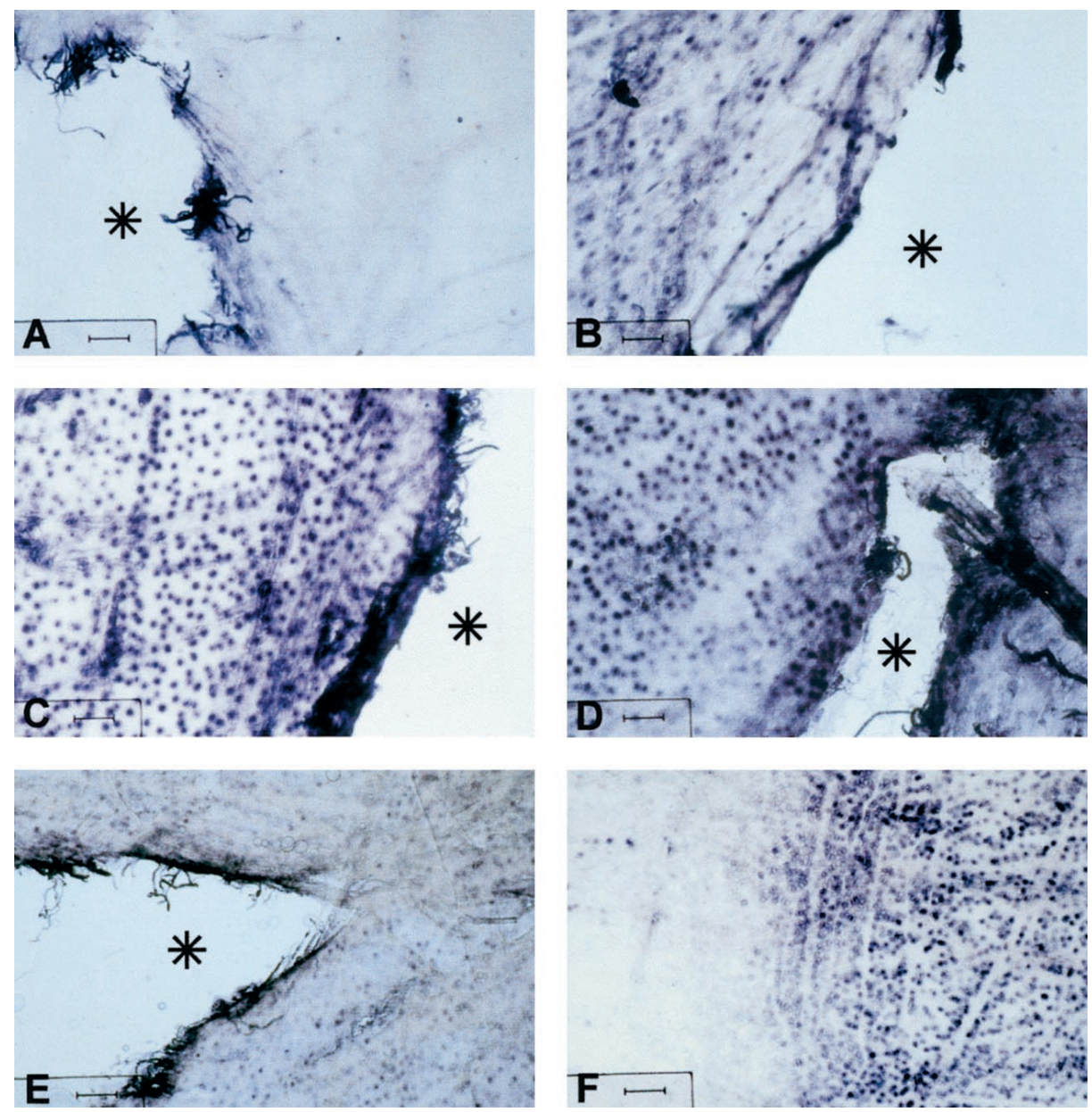

Figure 3. Thrombomodulin mRNA is upregulated after lesion of AMV. In situ hybridization of thrombomodulin mRNA after lesion of the AMV. AMV were taken at different times after lesioning and hybridized with a digoxigeninlabeled riboprobe, followed by immunodetection with an anti-digoxigenin-alkaline phosphatase antibody revealed by a diformazan precipitate. Times after lesion: $A, 0 \mathrm{hpl} ; B, 9 \mathrm{hpl} ; C, 1 \mathrm{dpl} ; D$, $F, 2 \mathrm{dpl} ; E, 6 \mathrm{dpl}$. The lesion is marked by asterisks in $A-E$, except in $F$ in which it is out of the field on the right. Note that, at $2 \mathrm{dpl}$ in $F$, there is a clear limit between thrombomodulin mRNA-positive (right) and mRNA-negative (left) cells, which might mark the limit of a front of astrocytosis (see Discussion). Scale bars, $100 \mu \mathrm{m}$.

\section{Thrombomodulin $m R N A$ expression after thrombin treatment}

The amount of thrombomodulin mRNA in astrocyte primary cultures treated once with $2 \mathrm{nM} \alpha$-thrombin was studied at different times using a quantitative RT-PCR mimic technique. Retrotranscription was performed with $3 \mu \mathrm{g}$ of total RNA extract. The competitive PCR was performed with the whole amount of cDNA and an increasing amount of mimic DNA. Fine-tuning of the competitive PCR amplification was performed with a twofold dilution series from $10^{-2}$ to $3 \cdot 10^{-4}$ amol of mimic DNA (Fig. 7). Thrombomodulin cDNA, reflecting the amount of thrombomodulin mRNA in astrocytes, was upregulated by thrombin. The increase in thrombomodulin mRNA levels was transient because it was doubled $9 \mathrm{hr}$ after treatment and increased by fivefold after $24 \mathrm{hr}$ (Fig. 7). The amount dropped to control levels by $48 \mathrm{hr}$ after treatment.

\section{DISCUSSION}

The transition of astrocytes from resting to reactive cells correlated with the expression of a wide range of new molecules (for review, see Ridet et al., 1997). Nevertheless, little is known about the mechanisms triggering astrogliosis. To the list of cytokines and growth factors implicated in the reaction of the CNS to injury, we can now add a new family of compounds, the serine proteases, signaling via one of the novel GPCR family, the PARs (for review, see Dery et al., 1998) and their inhibitors. Recently, gene expression of PAR-1 and the thrombin inhibitor PN1 was shown to be modulated in neurons after axotomy (Niclou et al., 1998).
Injury of the AMV induces a reactive astrogliosis (Berry et al., 1998) for which thrombomodulin is a transient marker. Thrombomodulin expression in vivo was very weak but increased after trauma, with a maximal expression at $2 \mathrm{dpl}$ corresponding to the approximate time needed to initiate astrogliosis (O'Brien et al., 1994; Hou et al., 1995). Thrombomodulin expression decreased
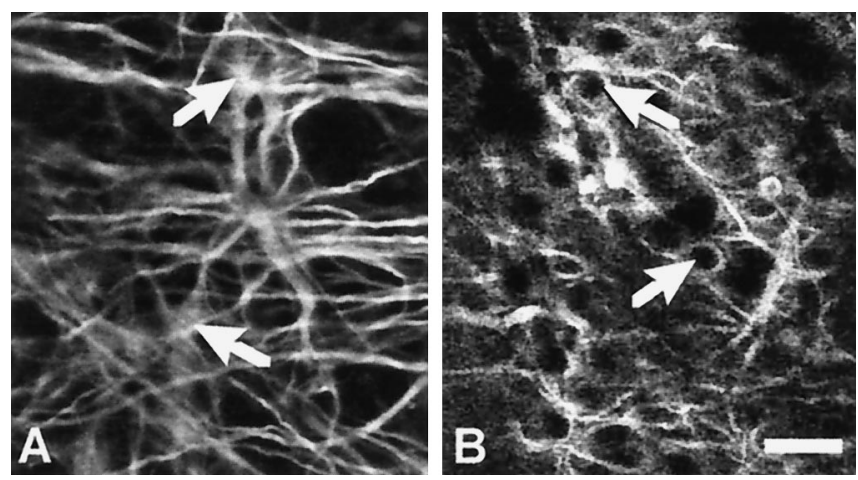

Figure 4. Astrocytes express thrombomodulin in AMV after lesioning. Immunohistochemistry of GFAP was performed after the in situ hybridization of thrombomodulin mRNA. Confocal immunolocalization of GFAP $(A)$ and of GFAP followed by thrombomodulin in situ hybridization $(B)$ in astrocytes in the $\mathrm{AMV}$ at $2 \mathrm{dpl}$. Note that the astrocyte somata (arrows), clearly visible in $A$, appear as black negative circles in $B$ after in situ hybridization because of the diformazan precipitate. This shows that astrocytes are the cells expressing thrombomodulin in the AMV. Scale bar, $50 \mu \mathrm{m}$. 

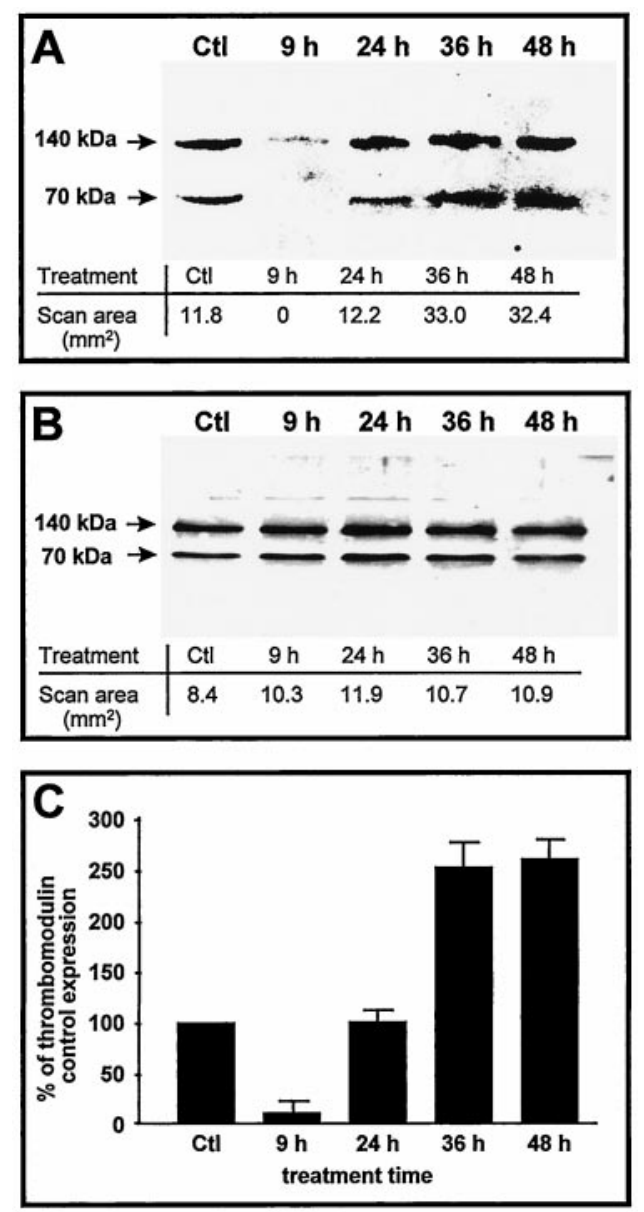

Figure 5. Time course of thrombin-induced modulation of thrombomodulin protein expression by astrocytes in culture; Western blot of thrombomodulin expression after thrombin treatment on rat primary astrocyte cultures. $A$, Cells were treated with $2 \mathrm{nM} \alpha$-thrombin for 9, 24, 36, and $48 \mathrm{hr}$. Control $(\mathrm{Ctl})$ were vehicle-treated astrocytes. Bands have been quantified using MCID program. $B$, As a control, we used the same time treatments with $2 \mathrm{nM} \alpha$-thrombin plus $10 \mathrm{U} / \mathrm{ml}$ hirudin. Bands have been quantified using MCID software. Membrane fractions were obtained by cell fractionation, and $10 \mu \mathrm{g}$ of proteins were loaded on $10 \%$ SDS-PAGE and then transferred on a nitrocellulose membrane. Monoclonal antibody against mouse thrombomodulin was used, and horseradish-peroxidase-conjugated secondary antibody was revealed by enhanced chemiluminescence. $C$, Quantification of thrombomodulin in membrane fraction. Data are expressed as the percentage of the control sample scan area. Results are mean of three independent experiments performed on three different astrocyte primary cultures. Error bars are SD.

later but always stayed elevated compared with controls. As we have shown previously (Pindon et al., 1997), thrombomodulin was expressed over the surface of the astrocyte plasma membrane, whereas GFAP stained only intermediate filaments; thus, thrombomodulin staining revealed the entire surface of astrocytes.

Variations in immunostaining of thrombomodulin reflect changes in thrombomodulin gene expression. However, we could not reject the hypothesis that the regulation of thrombomodulin expression over the astrocyte cell surface was by proteins released from vesicles in the vicinity of the plasma membrane (Maruyama and Majerus, 1985). There was no detectable thrombomodulin expression in normal conditions (Fig. $2 A$ ), but mRNA transcription occurred after lesioning (Fig. $3 B-E$ ). The kinetics of the gene expression were delayed compared with protein expression

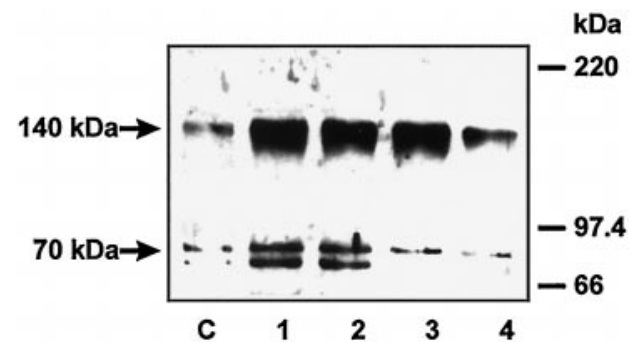

Figure 6. Upregulation of thrombomodulin protein expression by astrocytes in culture is attributable to the activation of PAR-1. Western blot of thrombomodulin after a dose-response treatment of TRAP-6. Primary astrocyte cultures were treated for $48 \mathrm{hr}$ with TRAP-6 (SFLLRN): untreated, $C ; 150 \mu \mathrm{M}, 1 ; 1.5 \mu \mathrm{M}, 2 ; 150 \mathrm{nM}, 3$; and $1.5 \mathrm{nM}, 4$. Membrane fractions were obtained by cell fractionation, and $10 \mu \mathrm{g}$ of proteins were loaded on $10 \%$ SDS-PAGE and then transferred on a nitrocellulose membrane. Polyclonal antibody against mouse thrombomodulin was used, and horseradish-peroxidase-conjugated secondary antibody was revealed by enhanced chemiluminescence.

of thrombomodulin, because mRNA was detectable from $9 \mathrm{hpl}$ with a maximum at $1 \mathrm{dpl}$.

We observed here that astrocytes expressing thrombomodulin mRNA spread from the lesion site into a restricted area of the surrounding tissue (Fig. $3 F$ ). This phenomenon might be linked to the observation that the response to a CNS lesion is characterized by a wave of reactive gliosis propagating outward from the lesion site (Mathewson and Berry, 1985; Logan and Berry, 1993). Here, we found that, because thrombomodulin is a transient marker of astrogliosis, it may mark the wave front of astrocyte reactivity. Thrombomodulin is not only a thrombin inhibitor but could also increase the cell-to-cell adhesion via its lectin homolog domain (Patthy, 1988; Petersen, 1988) and might stabilize the astrocyte processes forming the scar. The $\mathrm{N}$ terminus of thrombomodulin, like that of $\mathrm{E}$ selectin (another adhesion molecule that is also induced by thrombin on endothelial cells (Kaplanski et al., 1997), has been shown to belong to the C-type lectin family (Graves et al., 1994). Moreover, structure-function analysis of the $\mathrm{C}$-type lectin indicates a defined region containing specific amino acid side chains that may be involved in ligand binding (Graves et al., 1994; Villoutreix and Dalbäck, 1998). It has been suggested that an unknown ligand binds to the thrombomodulin lectin domain and triggers signal transduction pathways (Zhang et al., 1998).

Thrombin regulates thrombomodulin expression in vitro in hemangioma cells and smooth muscle cells (Dittman et al., 1989; Bartha et al., 1993; Ma et al., 1997). We wanted to know whether thrombin could induce similar regulation in astrocytes based on a model used to define the biochemical activity of thrombomodulin on newborn mouse cortical astrocyte primary cultures mediated by the formation of a thrombin-thrombomodulin complex (Pindon et al., 1997). The observation of Maruyama and Majerus (1985), that the thrombin-thrombomodulin complex is internalized and degraded, could explain our finding of thrombomodulin levels falling $9 \mathrm{hr}$ after a single thrombin treatment of astrocytes. Subsequently, thrombin induced a time-dependent increase of thrombomodulin expression in astrocytes doubling the amount $2 \mathrm{~d}$ after a single thrombin treatment. Two days was the time we chose to study the effect of TRAP-6, a specific activator of the GPCR PAR-1, on PAR-1 activation. This study demonstrated that responses induced in the brain are not attributable to a general proteolytic effect but involve an intracellular signaling mechanism in response to thrombin. 


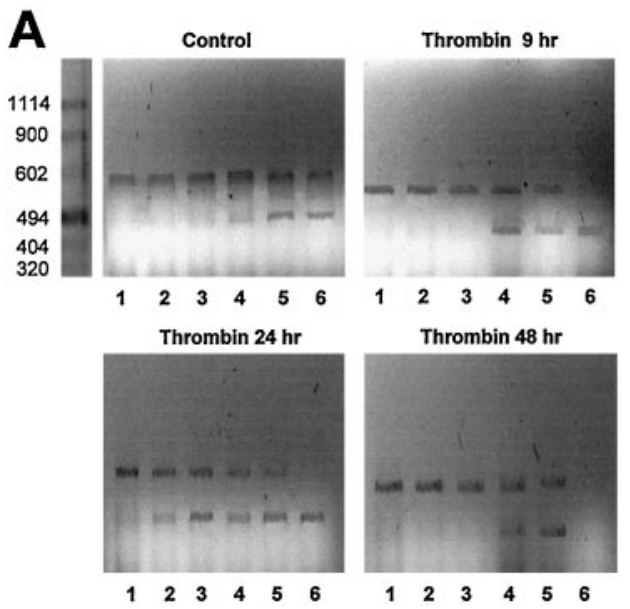

B

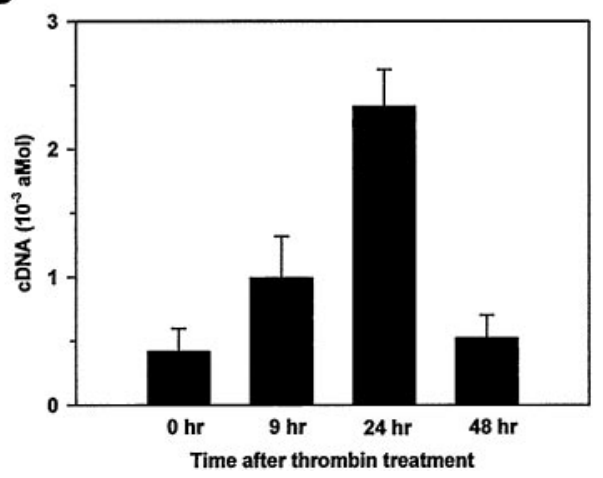

Figure 7. Thrombin upregulates thrombomodulin mRNA expression in cultured astrocytes; quantitative thrombomodulin mRNA expression at different times after thrombin treatment as measured by RT-PCR mimic. Astrocytes were treated with either $2 \mathrm{nM} \alpha$-thrombin for 9, 24, or $48 \mathrm{hr}$ or vehicle (Control). A, Reverse transcription was made with $3 \mu \mathrm{g}$ of astrocyte total RNA. PCR was performed with the whole product of the reverse transcription to which various concentrations of mimic were added: $10^{-2}$ amol (1); $5 \times 10^{-3}$ amol (2); $2.5 \times 10^{-3}$ amol (3); $1.25 \times$ $10^{-3}$ amol (4); $0.625 \times 10^{-3}$ amol (5); and $0.312 \times 10^{-3} \mathrm{amol}(6)$. The PCR amplimers were separated by electrophoresis on $1 \%$ agarose gels. The gel represents a typical experiment of three independent experiments from three independent astrocyte primary cultures. $B$, Thrombomodulin mRNA quantification performed by competitive RT-PCR mimic. Results are mean of three independent experiments from three different astrocyte primary cultures. Errors bars are SD.

The increase of thrombomodulin expression induced by thrombin was mediated by the specific receptor PAR-1 (Fig. 5). TRAP6 -induced thrombomodulin increased in a dose-dependent way. The efficient concentrations of TRAP-6-inducing thrombomodulin were similar to those found by Grabham and Cunningham (1995) to induce tyrosine phosphorylation in astrocytes. For lower concentrations, which did not induce tyrosine phosphorylation, we did not find thrombomodulin modulation. The PAR-1 activation on neurons induces neurite retraction, dependent on tyrosine kinase and phosphatase activities (Jalink and Moolenaar, 1992; Suidan et al., 1992). It will be interesting to know whether thrombomodulin variations are also dependent on tyrosine phosphorylations. These modulations are regulated at the transcriptional level because our quantitative RT-PCR showed that mRNA levels were increased fivefold $1 \mathrm{~d}$ after a single treatment (Figs. 6, 7); their subsequent decrease could be explained by the half-life of thrombomodulin $(8.9 \mathrm{hr})$ (Dittman et al., 1988), underlying the weak stability of this mRNA. The kinetics of the modulation of thrombomodulin mRNA levels are different from the protein; the bell-shaped increase in expression of mRNA occurred earlier after the treatments compared with that of the protein. At earlier stages after trauma, the appearance of new thrombomodulin could have been hidden by the internalization of the thrombin-thrombomodulin complex bound to free thrombin (Maruyama and Majerus, 1985).

The upregulation of thrombomodulin induced by PAR-1 activation supports the idea that thrombin acts in the first hour after trauma. Niclou and colleagues (1998) could not find any PAR-1 mRNA in astrocytes of the facial nerve by in situ hybridization $4 \mathrm{~d}$ after transection, but because $4 \mathrm{dpl}$ is already late for triggering astrogliosis, PAR-1 gene expression could have already been activated. In fact, the astroglial response takes place quite soon because GFAP gene expression can be detected $1 \mathrm{hr}$ after a mechanical lesion in transgenic mice bearing a GFAP-lacZ gene construct (Mucke et al., 1991). Moreover, thrombin infusion in the brain induces an infiltration of inflammatory cells, proliferation of mesenchymatous cells, angiogenesis, and increased astrocyte reactivity (Nishino et al., 1993). The availability of a specific PAR-1 antagonist would be useful to block thrombomodulin upregulation in vivo.

Together, these results support a strong correlation between the thrombin-thrombomodulin system and the initial induction of cellular and molecular astrogliosis events in reaction to CNS lesions.

\section{REFERENCES}

Bar-Shavit R, Kahn AJ, Mann KG, Wilner GD (1986) Growthpromoting effects of esterolytically inactive thrombin on macrophages. J Cell Biochem 32:261-272.

Bartha K, Brisson C, Archipoff G, de la Salle C, Lanza F, Cazenave JP, Beretz A (1993) Thrombin regulates tissue factor and thrombomodulin mRNA levels and activities in human saphenous vein endothelial cells by distinct mechanisms. J Biol Chem 268:421-429.

Beecher KL, Andersen TT, Fenton JW, Festoff BW (1994) Thrombin receptor peptides induce shape change in neonatal murine astrocytes in culture. J Neurosci Res 37:108-115.

Berry M, Ibrahim M, Carlile J, Ruge F, Duncan A, Butt AM (1995) Axon-glial relationships in the anterior medullary velum of the adult rat. J Neurocytol 24:965-983.

Berry M, Hunter AS, Duncan A, Lordan J, Kirvell S, Tsang W-L, Butt A (1998) Axon-glial relations during regeneration of axons in the adult rat anterior medullary velum. J Neurocytol 27:915-937.

Bignami A, Eng LF, Dahl D, Uyeda CT (1972) Localization of the glial fibrillary acidic protein in astrocytes by immunofluorescence. Brain Res 43:429-435.

Cavanaugh KP, Gurwitz D, Cunningham DD, Bradshaw RA (1990) Reciprocal modulation of astrocyte stellation by thrombin and protease nexin-1. J Neurochem 54:1735-1743.

Chomczynski P, Sacchi N (1987) Single-step method of RNA isolation by acid guanidinium thiocyanate-phenol-chloroform extraction. Anal Biochem 162:156-159.

Dery O, Corvera CU, Steinhoff M, Bunnett NW (1998) Proteinaseactivated receptors: novel mechanisms of signaling by serine proteases. Am J Physiol 43:1429-1452.

Dittman WA, Kumada T, Sadler JE, Majerus PW (1988) The structure and function of mouse thrombomodulin. Phorbol myristate acetate stimulates degradation and synthesis of thrombomodulin without affecting mRNA levels in hemangioma cells. J Biol Chem 263:15815-15822.

Dittman WA, Kumada T, Majerus PW (1989) Sequence of cDNA for mouse thrombomodulin and comparison of the predicted mouse and human amino acid sequences. Nucleic Acids Res 17:802.

Donovan FM, Cunningham DD (1998) Signaling pathways involved in thrombin-induced cell protection. J Biol Chem 273:12746-12752.

Ehrenreich H, Cosat T, Clouse KA, Pluta RM, Ogino Y, Coligan JE, 
Burd PR (1993) Thrombin is a regulator of endothelin-1. Brain Res 600:201-207.

Eng LF (1988) Astrocytic response to injury. In: Current issues in neuronal regeneration research (Reier P, Bunge R, Seil F, eds), pp 247255. New York: Liss.

Esmon CT (1987) The regulations of natural anticoagulant pathways. Science 235:1348-1352.

Grabham P, Cunningham DD (1995) Thrombin receptor activation stimulates astrocyte proliferation and reversal of stellation by distinct pathways: involvement of tyrosine phosphorylation. J Neurochem 64:583-591.

Grand RJA, Turnell AS, Grabham PW (1996) Cellular consequences of thrombin-receptor activation. Biochem J 313:353-368.

Graves BJ, Crowther RL, Chandran C, Rumberger JM, Li S, Huang KS, Presky DH, Familetti PC, Wolitzky BA, Burns DK (1994) Insight into E-selectin/ligand interaction from the crystal structure and mutagenesis of the lec/EGF domains. Nature 367:532-538.

Gurwitz D, Cunningham DD (1988) Thrombin modulates and reverses neuroblastoma neurite outgrowth. Proc Natl Acad Sci USA 85:3440-3444

Gustafson GT, Lerner U (1983) Thrombin, a stimulator of bone resorption. Biosci Rep 3:255-261.

Hou YJ, Yu AC, Garcia JM, Aotaki-Keen A, Lee YL, Eng LF, Hjelmeland LJ, Menon VK (1995) Astrogliosis in culture. IV. Effects of basic fibroblast growth factor. J Neurosci Res 15:359-370.

Imada M, Imada S, Iwasaki H, Kime A, Yamguchi H, Moore EE (1987) Fetomodulin: marker surface protein of fetal development which is modulatable by cyclic AMP. Dev Biol 122:483-491.

Imada S, Yamaguchi H, Nagumo M, Katayanagi S, Iwasaki H, Imada M (1990) Identification of fetomodulin, a surface marker protein of fetal development, as thrombomodulin by gene cloning and functional assays. Dev Biol 140:113-122.

Ishihara H, Connolly AJ, Zeng D, Khan ML, Zheng YW, Timmons C, Tram T, Coughlin SR (1997) Protease-activated receptor 3 is a second thrombin receptor in humans. Nature 386:502-506.

Jalink K, Moolenaar WH (1992) Thrombin receptor activation causes rapid neural cell rounding and neurite retraction independent of classic second messengers. J Cell Biol 118:411-419.

Kaplanski G, Fabrigoule M, Boulay V, Dinarello CA, Bongrand P, Kaplanski S, Farnarier C (1997) Thrombin induces endothelial type II activation in vitro: IL1 and TNF-alpha-independent IL-8 secretion and E-selectin expression. J Immunol 158:5435-5441.

Laemmli UK (1970) Cleavage of structural proteins during the assembly of the head of bacteriophage T4. Nature 227:680-685.

Logan A, Berry M (1993) Transforming growth factor-beta 1 and basic fibroblast growth factor in the injured CNS. Trends Pharmacol Sci 14:337-342.

Ma SF, Garcia JG, Reuning U, Little SP, Bang NU, Dixon EP (1997) Thrombin induces thrombomodulin mRNA expression via the proteolytically activated thrombin receptor in cultured bovine smooth muscle cells. J Lab Clin Med 129:611-619.

Maruyama I, Majerus PW (1985) The turnover of thrombinthrombomodulin complex in cultured human umbilical vein endothelial cells and A549 lung cancer cells. Endocytosis and degradation of thrombin. J Biol Chem 15:15432-15438.

Mathewson AJ, Berry M (1985) Observation on the astrocyte response to a cerebral stab wound in adult rats. Brain Res 327:61-69.

McCarthy K, Vellis JD (1980) Preparation of astroglial and oligodendroglial cell cultures from rat cerebral tissue. J Cell Biol 85:890-902.

Monard D (1993) Tinkering with certain blood components can engender distinct functions in the nervous system. Perspect Dev Neurobiol 1:165-168.

Mucke L, Oldstone MBA, Morris JC, Nerenberg MI (1991) Rapid activation of astrocyte specific expression of GFAP-lacZ transgene by focal injury. New Biol 3:465-474.
Neveu I, Jehan F, Jandrot-Perrus M, Wion D, Brachet P (1993) Enhancement of the synthesis and secretion of nerve growth factor in primary cultures of glial cells by proteases: a possible involvement of thrombin. J Neurochem 60:858-867.

Niclou SP, Suidan HS, Pavlik A, Vjsada R, Monard D (1998) Changes in the expression of protease-activated receptor 1 and protease nexin- 1 mRNA during rat nervous system development and after nerve lesion. Eur J Neurosci 10:1590-1607.

Nishino A, Suzuki M, Ohtani H, Motohashi O, Umezawa K, Nagura H, Yoshimoto T (1993) Thrombin may contribute to the pathophysiology of central nervous system injury. J Neurotrauma 10:167-179.

O'Brien MF, Lenke LG, Lou J, Bridwell KH, Joyce ME (1994) Astrocyte response and transforming growth factor-beta localization in acute spinal cord injury. Spine 15:2321-2329.

Patthy L (1988) Detecting distant homologies of mosaic proteins. Analysis of the sequences of thrombomodulin, thrombospondin complement components C9, C8 alpha and C8 beta, vitronectin and plasma cell membrane glycoprotein PC-1. J Mol Biol 202:689-696.

Perraud F, Besnard F, Sensenbrenner M, Labourdette G (1987) Thrombin is a potent mitogen for rat astroblasts but not for oligodendrocytes and neuroblasts in primary culture. Int J Dev Neurosci 5:181-188.

Petersen TE (1988) The amino-terminal domain of thrombomodulin and pancreatic stone protein are homologous with lectins. FEBS Lett 231:51-53.

Pindon A, Hantaï D, Jandrot-Perrus M, Festoff BW (1997) Novel expression and localization of active thrombomodulin on the surface of mouse brain astrocytes. Glia 19:259-268.

Pindon A, Festoff BW, Hantaï D (1998) Thrombin-induced reversal of astrocyte stellation is mediated by activation of protein kinase $\mathrm{C} \beta-1$. Eur J Biochem 255:766-774.

Ridet JL, Malhotra SK, Privat A, Gage FH (1997) Reactive astrocytes: cellular and molecular cues to biological function. Trends Neurosci [Erratum (1998) 21:80] 20:570-577.

Stone SR, Le Bonniec BF (1998) Thrombin. In: Handbook of proteolytic enzymes (Barret AJ, Rawlings ND, Woessner JF, eds), pp 168-174. London: Academic.

Suidan HS, Stone SR, Hennings BA, Monard D (1992) Thrombin causes neurite retraction in neuronal cells through activation of cell surface receptors. Neuron 8:363-375.

Suidan HS, Nobes CD, Hall A, Monard D (1997) Astrocyte spreading in response to thrombin and lysophosphatidic acid is dependent on the Rho GTPase. Glia 21:244-252.

Towbin H, Staehelin T, Gordon J (1979) Electrophoretic transfer of proteins from polyacrylamide gels to nitrocellulose sheets: procedure and some applications. Proc Natl Acad Sci USA 76:4350-4354.

Vaughan PJ, Pike CJ, Cotman CW, Cunningham DD (1995) Thrombin receptor activation protects neurons and astrocytes from cell death induced by environmental insults. J Neurosci 15:5389-5401.

Villoutreix BO, Dalbäck B (1998) Molecular model for the C-type lectin domain of human thrombomodulin. J Mol Modeling 4:310-312.

Vu TK, Hung DT, Wheaton VI, Coughlin SR (1991) Molecular cloning of a functional thrombin receptor reveals a novel proteolytic mechanism of receptor activation. Cell 64:1057-1068.

Walz W (1989) Role of glial cells in the regulation of the brain ion neuroenvironment. Prog Neurobiol 33:309-333.

$\mathrm{Xu}$ WF, Andersen H, Whitmore TE, Presnell SR, Yee DP, Ching A, Gilbert T, Davie EW, Foster DC (1998) Cloning and characterization of human protease-activated receptor 4. Proc Natl Acad Sci USA 95:6642-6646.

Zhang Y, Weiler-Guettler $\mathrm{H}$, Chen J, Wilhelm O, Deng Y Qiu F, Nakagawa K, Klevesath M, Wilhelm S, Bohrer H, Nakagawa M, Graeff H, Martin E, Stern DM, Rosenberg RD, Ziegler R, Nawroth PP (1998) Thrombomodulin modulates growth of tumor cells independent of its anticoagulant activity. J Clin Invest 1017:1301-1309. 